\title{
Stimulating Effect of Fur Seal Muscle Hydrolysate Peptides on Contractile Activity of Actomyosin ${ }^{* 1}$
}

\author{
Juichiro J. Matsumoto*2, Taneko Suzukr ${ }^{* 3}$, Yoshio Asaka*2, \\ Noriyasu TAMakI ${ }^{* 2}$, Haruo MinaguCHI ${ }^{* 2}$, Satoshi UtsugI ${ }^{* 2}$, \\ and Toru TAMIYA*2
}

(Received April 15, 1976)

\begin{abstract}
This work was undertaken as an introductory step for isolating the biologically active components of the hydrolysate preparation of fur seal skeletal muscle proteins which contain some vasoactive factors as reported previously. This study was carried out with 2 preparations obtained at different fractionation stages, i.e., "unfractionated mixture" and "lyophilized powder", the latter constituting the second fraction of gel filtration (Sephadex $\mathrm{G}-25$ ) of the former. The 2 preparations differed in peptide composition, because their relative biuret, ninhydrin and ultraviolet absorption values differed respectively. By paperand thin layer-chromatography, peptide mapping as well as ion exchange column chromatography, both preparations were found to contain more than 22 peptide components, though the lyophilized powcer had less than the other.

The lyophilized powder showed an accelerating effect on the rates of both superprecipitation (0.1 ionic strength, pH 7.0) and ATPase activity (0.15 ionic strength, $\mathrm{pH} 6.4)$ of fish actomyosins. The acceleration was also positive when $\mathrm{Ca}$ and $\mathrm{Mg}$ ions were removed by adding GEDTA or EDTA. These effects seem to be involved in the vasoactive and vasodilatory function of the fur seal peptide preparation.
\end{abstract}

Presence of a new vasoactive peptide in hydrolysate of the fur seal skeletal muscle has been reported by HAYASHI et al. ${ }^{13}$ and HAYASHI and SUZUKI ${ }^{2)}$ and the peripheral vasodilating action, i.e. blood flow increasing effect, of the peptides has been proposed by MATSUKAWA et al. ${ }^{3)}$ and SUzUKI et al. ${ }^{4}$

With the aim to clarify the nature and the functional mechanism of the above vasoactive effects, the authors took up a study to isolate each peptide component, to search for the real active one, and, further, to reveal the biochemical mechanism of the effects. The present paper deals with the analysis of the peptide components as well as the finding of stimulating effects of the peptides on contractile activity of fish muscle actomyosin.

*1 This paper was presented at the Annual Meeting of the Japanese Society of Scientific Fisheries on April 3, 1972, Tokyo: Contribution B 629 from the Tokai Regional Fisheries Research Laboratory, Fisheries Agency.

*2 Department of Chemistry, Sophia University, Kioi-cho 7, Chiyoda-ku, Tokyo, 102 (松本重一郎 浅賀良雄・玉木憲康・水口晆夫・宇津木敏・田宮 徽：上智大学理工学部)

*3 Tokai Regional Fisheries Research Laboratory, Kachidoki 5-5-1, Chuo-ku, Tokyo 104 (铃木

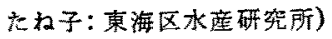




\section{Materials and Methods}

Fur seal Skeletal muscles of fur seal, Callorhinus ursinus, caught in the waters off Hokkaido for investigation were obtained by the courtecy of the Fur Seals Research Section of Far Sea's Fisheries Laboratory, Fisheries Agency. The muscles were frozen at $-20^{\circ} \mathrm{C}$ until use. The biological data of the material animals are comparable with those given in the previous paper ${ }^{4}$, but, in the present work, several pieces of muscle from different animals were mixed and used for each lot of preparation.

Preparation of peptides Preparation was carried out according to the method of HAYASHI et al. ${ }^{2}$ ) The ethanol soluble fraction of the hydrolysate is referred to in this study as the "unfractionated mixture," and the final lyophilized preparation of the second peak (Fraction $2^{23}$ ) obtained by gel-filtration through Sephadex G-25, as the "lyophilized powder." The unfractionated mixture was a yellowish brown fluid liquid, while the lyophilized powder was yellowish white and hygroscopic. The latter was readily soluble in water as well as in aqueous ethanol below the concentration of $70 \%$ ethanol beyond which insoluble matter increased with the raise of the ethanol concentration.

Fish actomyosin The method described previously ${ }^{5)}$ was applied for preparation using live muscles of either carp, Cyprinus carpio, or stone flounder, Kareis bicoloratus.

Paper chromatography Filter Paper, Toyo No. $50,40 \times 40 \mathrm{~cm}^{2}$; developing solvents, $n$-BuOH$-\mathrm{CH}_{3} \mathrm{COOH}-\mathrm{H}_{2} \mathrm{O}(4: 1: 2)$ followed by $\mathrm{PhOH}-\mathrm{H}_{2} \mathrm{O}(4: 1)$; localization of spots, ninhydrin reaction.

Thin layer chromatography Silica gel $0.5 \mathrm{~mm}$ thick, $20 \times 20 \mathrm{~cm}^{2}$; developing solvents, $\mathrm{PrOH}-\mathrm{H}_{2} \mathrm{O}(7: 3)$ followed by $n-\mathrm{BuOH}-\mathrm{CH}_{3} \mathrm{COOH}-\mathrm{H}_{2} \mathrm{O}(4: 1: 2)$; localization of stops, ninhydrin reaction.

Peptide map method With filter paper, Toyo No. $51\left(14 \times 24 \mathrm{~cm}^{2}\right)$, chromatography was done with $n$ - $\mathrm{BuOH}-\mathrm{CH}_{3} \mathrm{COOH}-\mathrm{H}_{2} \mathrm{O}(4: 1: 2)$ followed by electrophoresis at constant current $(1 \mathrm{~mA} / \mathrm{cm}$ width) using acetate buffer (ionic strength $0.05, \mathrm{pH} 4)$. The spots were detected by ninhydrin reaction.

Ion exchange chromatography Sample solution, $600 \mathrm{mg} / \mathrm{ml}$, was adapted on Dowex 50-X2 column (diameter $1.5 \mathrm{~cm}$, length $70 \mathrm{~cm}$ ) and eluted stepwise with $\mathrm{Na}_{2} \mathrm{HPO}_{4}$ $(0.2 \mathrm{M})$-citrate $(0.1 \mathrm{M})$ buffers of varying mixing ratio for $\mathrm{pH} 3 \sim 8$ as well as with $\mathrm{Na}_{2} \mathrm{CO}_{3}(0.1 \mathrm{M})$ buffer for $\mathrm{pH} 9$.

Superprecipitation The change in turbidity after adding ATP to the actomyosin suspension was observed either visually or spectrophotometrically at $660 \mathrm{~nm}$, under the following reaction conditions: Stone flounder actomyosin, $0.5 \sim 1 \mathrm{mg} / \mathrm{m} l$; ionic strength, $0.1 ; \mathrm{KCl}, 60 \mathrm{~mm}$; tris buffer, $40 \mathrm{~mm}(\mathrm{pH} 7.0)$; ATP, $0.2 \mathrm{mM}$; peptides, $0.5 \sim 2.5 \mathrm{mg} / \mathrm{ml}$. ATPase activity Activity was measured by determining the liberated inorganic 
phosphate by FISKE-SUBBAROw's method ${ }^{())}$after stopping the reaction with trichloroacetic acid. Conditions of the enzymatic reaction are as follows: Carp actomyosin, $0.2 \mathrm{mg} / \mathrm{ml}$; ionic strength, $0.15 ; \mathrm{KCl}, 100 \mathrm{~mm}$; tris buffer, $50 \mathrm{~mm}$ (pH 6.4); ATP, $1.3 \mathrm{~mm}$; peptide, $0.42 \mathrm{mg} / \mathrm{ml}$; EDTA, $1 \mathrm{~mm} ; 25^{\circ} \mathrm{C}$.

Biuret reaction The method of MATSUMoto et al. ${ }^{7 /}$ was used.

Ninhydrin reaction For paper chromatography and thin layer chromatography, $0.1 \%$ ninhydrin solution in water-saturated $n-\mathrm{BuOH}$ was sprayed and spots were detected by heating at $90 \sim 100^{\circ} \mathrm{C}$ for $5 \mathrm{~min}$. For column chromatography, $\mathrm{KCN}$-ninhydrin solution was used according to YEMM and COCKING. ${ }^{8)}$

Ultraviolet absorption Absorbance at $270 \mathrm{~nm}$ was measured.

\section{Results}

General properties of peptide preparations The properties of the lyophilized powder were as follows: Nitrogen content, $13.65 \%$; phosphorus, not detectable by FiskeSUBBARow's method ${ }^{8\rangle}$ after hydrolysis with $\mathrm{NaOH}$; ultraviolet absorption, strong at $270 \mathrm{~nm}$; reaction, positive to biuret, ninhydrin, and PAULI-EHRLICH tests, and negative to SAKaguchI test.

The absorbance values produced by the routine biuret ${ }^{7)}$ and ninhydrin ${ }^{8)}$ reactions and by direct ultraviolet measurement were compared for both the lyophilized powder and the unfractionated mixture as shown in Table 1: The difference in the ratio of the

Table 1. Relationships between absorbance values of the biuret ${ }^{7)}$ and ninhydrin ${ }^{8)}$ reactions and of the ultraviolet absorption of lyophilized powder and unfractionated mixture of fur seal peptides

\begin{tabular}{lccc}
\hline & \multicolumn{2}{c}{ Lyophilized powder } & $\begin{array}{c}\text { Unfractionated } \\
\text { mixture } \\
\text { Ratio*2 }\end{array}$ \\
\cline { 2 - 3 } & $\begin{array}{c}\text { Absorption } \\
\text { coefficient*1 }\end{array}$ & Ratio & 1 \\
\hline Biuret reaction $(545 \mathrm{~nm})$ & 0.510 & 1 & 49.0 \\
Ninhydrin reaction $(570 \mathrm{~nm})$ & 20.3 & 39.8 & 23.6 \\
Ultraviolet absorption $(270 \mathrm{~nm})$ & 6.38 & 12.5 & 1 \\
\hline
\end{tabular}

*1 The figures of the absorption (extinction) coefficient (per $1 \mathrm{~g} / \mathrm{d} l$ and per $1 \mathrm{~cm}$ depth) of biuret and ninhydrin reactions were obtained by each routine procedure described in the methods section, ${ }^{7,8)}$ and those of ultraviolet absorption by direct measurement of the intact or diluted solutions.

*2 Because the unfractionated mixtures are in liquid state with various concentration levels, only the relative values of absorbance are shown here.

absorbance values obtained by the three methods suggests that the peptide composition of the two preparations at different fractionation stages is different.

Presence of high molecular substances in the lyophilized powder and the unfractionated mixture was refuted by ultracentrifugal analysis and by dialysis test where all 
the biuret-positive matters were removed through a commercial dialysis membrane.

Analysis of peptide components By two-dimensional paper chromatography, 17 spots have been detected in the unfractionated mixture, while 16 spots were found in the lyophilized powder as shown in Fig. 1. Also, thin layer chromatography of the lyophilized powder gave a pattern shown in Fig. 2, where 13 to 15 spots were detectable. The

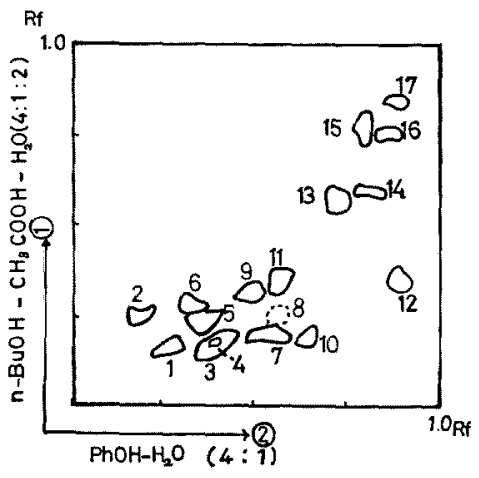

(a) Unfractionated mixture

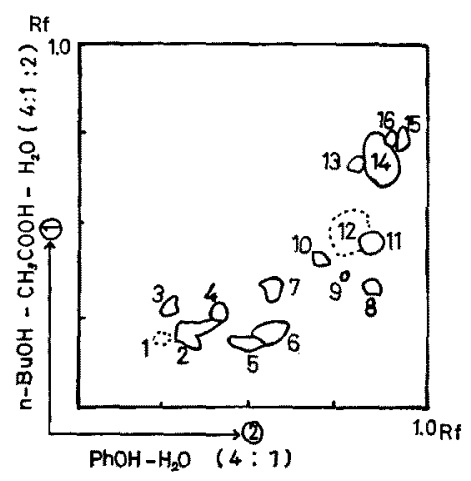

(b) Lyophilized powder

Fig. 1. Two-dimensional paper chromatography of fur seal peptide preparations.

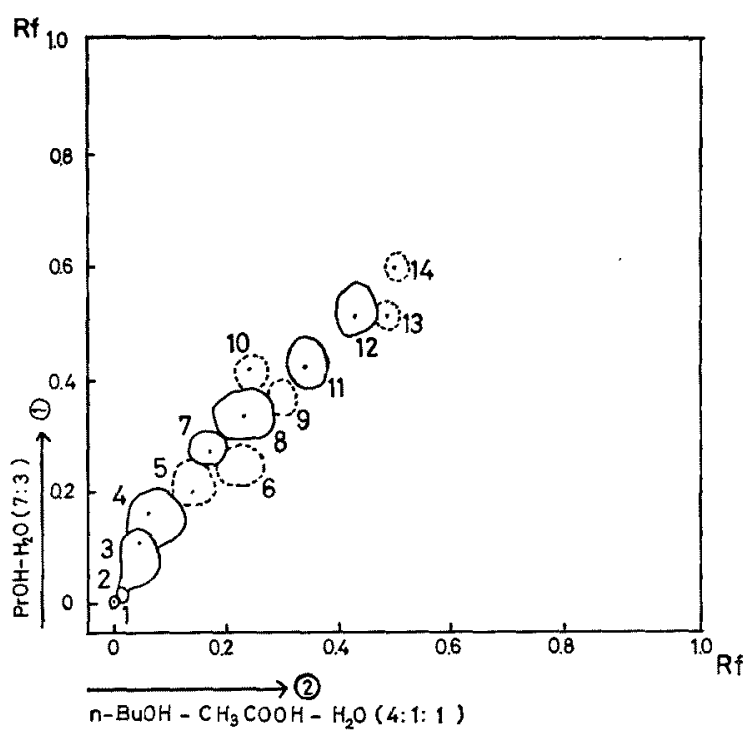

Fig. 2. Two-dimensional thin layer chromatography of lyophilized powder of fur seal peptides.

peptide-map method revealed 22 spots for the lyophilized powder as shown in Fig. 3.

By ion exchange chromatography, the lyophilized powder showed 18 peaks as shown in Fig. 4. The optical density ratios of the biuret reaction value to the ninhydrin reac- 


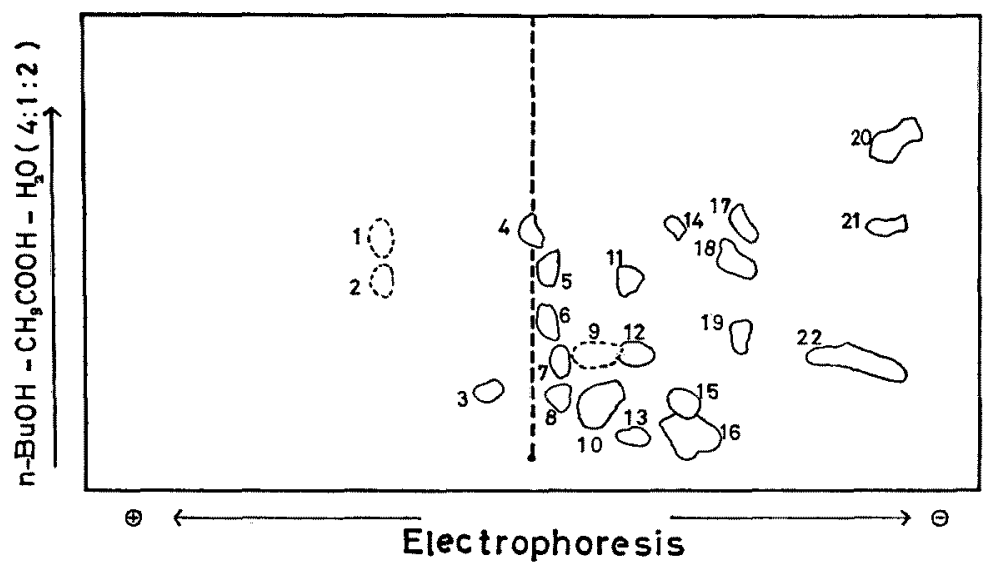

Fig. 3. Peptide map of lyophilized powder of fur seal peptides. Paper chromatography was succeeded by electrophoresis.

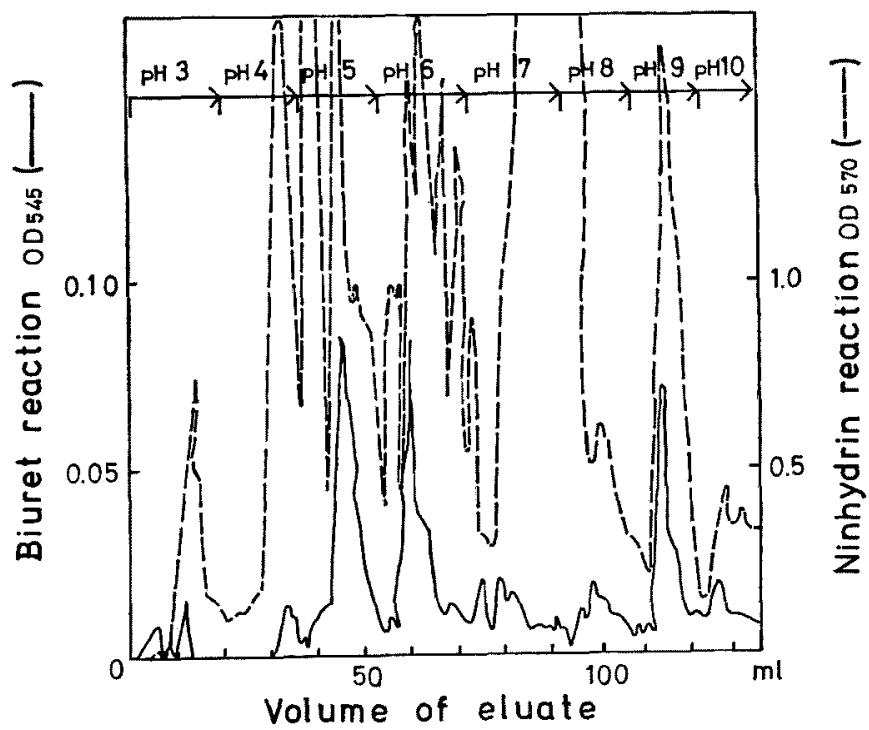

Fig. 4. Ion exchange column chromatography of lyophilized powder of fur seal peptides.

tion value given by corresponding peaks are variable from one peak to another, indicating that the peptide composition of each peak is different. Most of the peak components obtained by the ion exchange chromatography showed few spots in onedimensional paper or thin layer chromatography.

Silica gel adsorption chromatography with Wako Q12 silica gel and acetate buffer $(0.04 \mathrm{M}, \mathrm{pH} 4)$ showed successful separation to some extent, but appeared impracticable because of its poor results in reactivation of the column. 
The above data altogether show that the lyophilized powder, though it has been gel filtered, is a mixture of more than 20 different peptides and the unfractionated mixture contains more. Further separation study will be reported in the succeeding papers.

Biochemical activity Previously, the peptides in the hydrolized fur seal muscle proteins have been reported to have the peripheral vasodilatory effect ${ }^{3)}$. Since the effect might be related with some modification of the activity of blood vessel smooth muscle, the peptide preparations have been tested for effects on the biochemical activities of actomyosin, such as superprecipitation and ATPase activity, which are related with the muscular contraction.

When $0.25 \%(w / v)$ lyophilized powder was added to the reaction mixture prior to adding ATP, superprecipitation of the stone flounder actomyosin proceeded more quickly as compared with the case without the lyophilized powder (Table 2). Also, on removal of

Table 2. Rate of superprecipitation of stone flounder actomyosin in the presence and absence of lyophilized powder of fur seal peptides and GEDTA as expressed in the time (min) needed for reaching definite stages in the process of superprecipitation

\begin{tabular}{|c|c|c|c|c|c|c|}
\hline \multicolumn{3}{|c|}{ Condition } & \multicolumn{4}{|c|}{ Stages in superprecipitation } \\
\hline & Peptide & GEDTA & Clearing & $\begin{array}{l}\text { Fine } \\
\text { particulate } \\
\text { aggregates } \\
\text { formed }\end{array}$ & $\begin{array}{l}\text { Massive } \\
\text { aggregates } \\
\text { formed }\end{array}$ & $\begin{array}{c}\text { Aggregates } \\
\text { deposited }\end{array}$ \\
\hline \multirow[t]{3}{*}{ Control } & - & - & $10 \mathrm{~min}$ & $15 \mathrm{~min}$ & $20 \mathrm{~min}$ & $35 \mathrm{~min}$ \\
\hline & + & - & $4 \prime$ & $7 "$ & $10 "$ & $15 "$ \\
\hline & + & + & 4 & $7 "$ & $12 "$ & $16 "$ \\
\hline
\end{tabular}

Conditions: Ionic strength, $0.1 ; \mathrm{pH} 7.0$; actomyosin, $1 \mathrm{mg} / \mathrm{ml} ; \mathrm{KCl}, 60 \mathrm{~mm}$; tris buffer, $40 \mathrm{~mm}$; ATP, $0.2 \mathrm{mM}$; peptide, $2.5 \mathrm{mg} / \mathrm{ml}$; GEDTA, $0.25 \mathrm{mg} / \mathrm{m} / ; 20^{\circ} \mathrm{C}$.

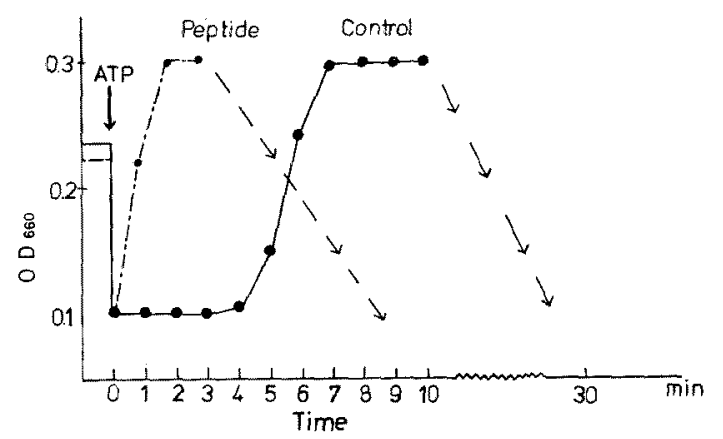

Fig. 5. Superprecipitation of stone flounder actomyosin in the presence and absence of lyophlized powder of fur seal peptides as expressed by the turbidity illustrated in absorbance (OD) at $660 \mathrm{~nm}$.

Ionic strength, $0.1 ; \mathrm{pH} 7.0$; actomyosin, $0.5 \mathrm{mg} / \mathrm{ml} ; \mathrm{KCl}, 60 \mathrm{mM}$; tris buffer, $40 \mathrm{~mm}$; ATP, $0.2 \mathrm{~mm}$ peptide, $0.5 \mathrm{mg} / \mathrm{ml} ; 20^{\circ} \mathrm{C}$. 
$\mathrm{Ca}$ ions by adding GEDTA, similar acceleration was found. Such acceleration by the peptide preparation was confirmed quantitatively by turbidity measurement as shown in Fig. 5.

Besides the superprecipitation, effect of the peptides in the lyophilized powder was tested by comparing the rate of ATP splitting in the presence $(5.3 \mathrm{mg} / \mathrm{ml})$ and the absence of the peptides, resulting in proving the accelerated splitting rate by the peptides (Fig. 6).

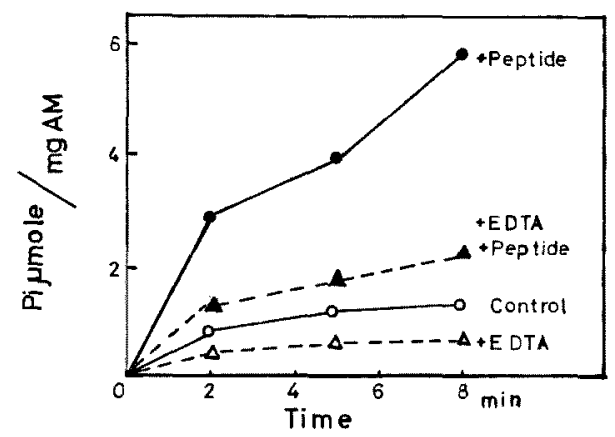

Fig. 6. ATPase activity of carp actomyosin in the presence and absence of lyophilized poweder of fur seal peptides as well as EDTA.

Ionic strength, 0.15; pH 6.4; actomyosin (AM), $0.2 \mathrm{mg} / \mathrm{ml} ; \mathrm{KCl}, 100 \mathrm{mM}$; tris buffer, $50 \mathrm{~mm}$; ATP, $1.3 \mathrm{~mm}$; peptide, $0.42 \mathrm{mg} / \mathrm{ml}$; EDTA, $1 \mathrm{mM} ; 25^{\circ} \mathrm{C}$.

Since it was suspected that the effect might be due to $\mathrm{Ca}$ or $\mathrm{Mg}$ ions contained in the peptide preparation, a parallel set of experiments was carried out with added EDTA to chelate $\mathrm{Ca}$ and $\mathrm{Mg}$ ions. With EDTA, the rate of ATPase activity was reduced but it was accelerated by the peptide preparation. For checking the ATP splitting effect of the peptide preparation itself, ATP was incubated with it without actomyosin, but any decomposition of ATP was not recognized. These results show the acceleration is due to the fur seal peptides (lyophilized powder).

A possibility that added EDTA was not sufficient to chelate all the $\mathrm{Ca}$ and/or $\mathrm{Mg}$ jons contained in the peptide preparation is left for doubt, but it was disproved by the electrophoretic preparative study as reported in the succeeding paper.

\section{Discussion}

The present results prove the activity of the fur seal muscle hydrolysate preparations to accelerate the superprecipitation and the ATPase activity of stone flounder and carp actomyosin. Hence, the effect of the fur seal peptides on the contractile system of the muscles of blood vessels might be involved in the previously reported vasoactive effects of the peptides, such as dilation of cortical vascular system of $\mathrm{cat}^{2}$, dilation of blood 
vessels and hypotension of rabbit ${ }^{2,3)}$, and blood flow increase and blood pressure lowering of $\operatorname{dog}^{4)}$. Although data are not sufficient as to reject a possible effect on the regulatory nerve system, the present postive data of the in vitro experiments on the isolated contractile system itself, i.e. actomyosin, suggest that the contractile system itself has undergone some effect of the peptides.

The present experiments were carried out with fish actomyosin, but the similar results are expected with the mammalian actomyosins, because the difference in the properties of actomyosin system is not so substantial between mammals and fishes as far as known so far.

\section{Acknowledgement}

The authors wish to express their gratitude to the late Dr. Takashi HAYASHI and Dr. Haruo Iто for advice and to Mrs. Seeko Kato for technical support. The authors are also indebted to the members of the Fur Seals Research Section of Far Sea's Fisheries Laboratory for providing with the fur seal muscles.

\section{References}

1) T. Hayash, T. Otsuka, S. Arkawa, and H. Hoshino: Keio J. Med., 15, 227-243 (1966).

2) T. HAYASHI and T. SUzUKI: This Bull., 33, 1044-1049 (1967).

3) H. Matsukawa, H. Ito, and T. Suzukr: ibid., 40, 1139-1143 (1974).

4) T. SuzuKr, H. Matsukawa, and H. Iro: ibid., 40, 1195-1197 (1974).

5) S. NoGUCh and J. J. MATSUMoto: ibid., 36, 1078-1087 (1970).

6) C. H. Fiske and Y. SubBarow: J. Biol. Chem., 66, 375-400 (1925).

7) J. J. Matsumoto and T. Kanamitsu: This Bull., 21, 284-288 (1955).

8) E. W. Yemm and E. C. Cocknng: Analyst, 80, 209-213 (1955). 